\title{
Ibrutinibrezisztencia krónikus limfocitás leukémiában
}

\author{
Aczél Dóra $^{1}$, Mátrai Zoltán ${ }^{2}$, Kiss Richárd ${ }^{1}, B$ alogh Alexandra ${ }^{3}$, Illés Sarolta ${ }^{3}$, \\ Bödör Csaba ${ }^{1}$, Alpár Donát ${ }^{1, @ ~}$
}

\author{
${ }^{1}$ MTA-SE Lendület Molekuláris Onkohematológia Kutatócsoport, \\ I. sz. Patológiai és Kísérleti Rákkutató Intézet, Semmelweis Egyetem, Budapest \\ ${ }^{2}$ Országos Hematológiai és Infektológiai Intézet, Dél-pesti Centrumkórház, Budapest \\ ${ }^{3}$ III. sz. Belgyógyászati Klinika, Semmelweis Egyetem, Budapest
}

\begin{abstract}
A krónikus limfocitás leukémia a nyugati világban leggyakrabban előforduló felnőttkori leukémiatípus, mely heterogén klinikai lefolyással és változatos genetikai háttérrel társul. A széles körben alkalmazott kemo-immunoterápiák mellett az elmúlt években új, célzott kezeléseket biztosító kis molekulájú gyógyszerek váltak elérhetővé, mint a kinázgátló ibrutinib, acalabrutinib és idelalisib, valamint a BCL2 antagonista venetoclax. Jelenleg hazánkban a krónikus limfocitás leukémia terápiáját forradalmasító, korszerü kezelések közül az ibrutinib monoterápia nemcsak relabáló vagy refrakter betegeknél, hanem rossz prognózisú, TP53-defektust hordozó betegeknél első vonalban is alkalmazható. A látványos klinikai sikerek ellenére a betegek egy részében rezisztencia alakul ki ibrutinibkezelés mellett, melynek hátterében álló genetikai változásokhoz és molekuláris mechanizmusokhoz kapcsolódóan egyre több adat áll rendelkezésre a nemzetközi irodalomban. Közleményünkben ismertetjük a B-sejt receptor jelátviteli útvonalnak a krónikus limfocitás leukémia patogenezisében betöltött szerepét, mely egyúttal az ibrutinibkezelés célpontjaként is szolgál. Továbbá bemutatjuk az ibrutinibterápia hatásmechanizmusát és sajátosságait, valamint a kezelés során megjelenő, klinikai rezisztenciát kísérő genetikai változásokat. Végül áttekintjük a terápiás rezisztencia molekuláris módszerekkel való monitorozásának és korai kimutatásának lehetőségeit és korlátait, valamint a rezisztencia megjelenését követően alkalmazható kezelési lehetőségeket.
\end{abstract}

Kulcsszavak: CLL, ibrutinib, célzott kezelés, terápiás rezisztencia, molekuláris monitorozás

\section{Ibrutinib resistance in chronic lymphocytic leukemia}

Chronic lymphocytic leukemia is the most common leukemia in adults in the Western countries, associated with diverse genomic, epigenomic and transcriptomic landscapes, as well as a heterogeneous clinical course. Besides the widely used chemoimmunotherapies, novel small molecules have recently become available for the targeted treatment of this oncohematological malignancy, such as the kinase inhibitors ibrutinib, acalabrutinib and idelalisib, as well as the BCL2 antagonist venetoclax. Among the new treatment options revolutionizing the clinical management of chronic lymphocytic leukemia, ibrutinib monotherapy in Hungary can be administered to patients with refractory or resistant disease and also, as a frontline treatment, to patients with TP53-defect conferring dismal prognosis. Despite the pronounced clinical success rate, a subset of the patients keep developing resistance to ibrutinib therapy and data on the related molecular mechanisms and on associated genetic changes is accumulating in the literature. In this review, we outline the role of B-cell receptor signaling in the pathogenesis of chronic lymphocytic leukemia, a mechanism targeted by ibrutinib; furthermore, features of ibrutinib therapy and genetic lesions associated with clinical resistance will be described. Finally, we discuss options and limitations of molecular monitoring and early detection of treatment resistance, as well as summarize alternative treatment strategies available upon ibrutinib resistance.

Keywords: CLL, ibrutinib, targeted therapy, treatment resistance, molecular monitoring

(Beérkezett: 2019. március 28.; elfogadva: 2019. június 13.)

@ Levelezési cím: Dr. Alpár Donát, Semmelweis Egyetem, I. sz. Patológiai és Kísérleti Rákkutató Intézet, 1085 Budapest, Üllői út $26 . ;$ Tel.: 0036-1-459-1500/54462; E-mail: alpar.donat@med.semmelweis-univ.hu 


\section{Rövidítések}

$\mathrm{Ag}=$ antigén (antigen); $\mathrm{ATP}=$ adenozin-trifoszfát (adenosine triphosphate); $\mathrm{BCR}=\mathrm{B}$-sejt receptor (B-cell receptor); $\mathrm{BTK}=$ Bruton-féle tirozin kináz (Bruton's tyrosine kinase); $\mathrm{C} 481 \mathrm{~S}=\mathrm{a}$ 481-es cisztein szerin aminosavra történő mutációja; CLL = krónikus limfocitás leukémia (chronic lymphocytic leukemia); $\mathrm{CR}=$ komplett válasz (complete response); CXCL12 = kemokin $(\mathrm{C}-\mathrm{X}-\mathrm{C}$ motívum) ligand 12 (C-X-C motif chemokine 12$)$; Cys481 = A Bruton-féle tirozin kináz, tirozin kináz doménjén található 481-es cisztein aminosav; DAG = diacilglicerol (diacylglycerol); ddPCR = digitális droplet polimeráz láncreakció (droplet digital polymerase chain reaction); ERK $1 / 2=$ extracelluláris jel által regulált kináz 1 (extracellular signal-regulated kinase $1 / 2$ ); FCR = fludarabin + ciklofoszfamid + rituximab (fludarabine + cyclophosphamide + rituximab); FISH = fluoreszcencia in situ hibridizáció (fluorescence in situ hybridization); FOXO = Forkhead box O transzkripciós faktor (Forkhead box $O$ transcription factor); GSK3 = glikogén szintáz kináz 3 (glycogen synthase kinase 3); IBR = ibrutinib (ibrutinib); $\operatorname{Ig} \alpha$ és $\operatorname{Ig} \beta=$ immunglobulin $\alpha$ és $\beta$ lánc (immunglobulin $\alpha$ and $\beta$ chain); IGHV = immunglobulinnehézlánc variábilis gén szegmens (immunoglobulin heavy chain variable gene segment); $\mathrm{IKK}=\mathrm{I} \kappa \mathrm{B}$ kináz (I $\mathrm{KB}$ kinase), $\mathrm{IP}_{3}=$ inozitol-1,4,5-triszfoszfát (inositol 1,4,5-trisphosphate); ITK = IL2-indukált T-sejt kináz (IL2 inducible T-cell kinase); Klo = klorambucil (chlorambucil); Lyn = Lck/Yes novel tirozin kináz (Lck) Yes novel tyrosine kinase); MAPK = mitogén aktiválta protein kináz (mitogen-activated protein kinase); m-IGHV = mutált-IGHV (mutated-IGHV) mTORC1/2 mammalian target of rapamycin complex $1 / 2 ; \mathrm{NF}-\kappa \mathrm{B}=$ nukleáris faktor $\mathrm{\kappa B}$ (nuclear factor kappalight-chain-enhancer of activated $B$ cells); NFAT = aktivált T-sejt nukleáris faktor (nuclear factor of activated T-cells); NGS = új generációs szekvenálás (next-generation sequencing); $\mathrm{NK}$ sejt = természetes ölösejt (natural killer cell); Obi = obinutuzumab (obinutuzumab); Ofa = ofatumumab (ofatumumab); ORR = teljes válaszadási arány (overall response rate); OS = teljes túlélés (overall survival); $\mathrm{PCL}=$ Piccolo preszinaptikus citomátrix fehérje (Piccolo Presynaptic Cytomatrix Protein); PDK1 = foszfoinozitidfüggő kináz 1 (phosphoinositide-dependent protein kinase-1); $\mathrm{PI} 3 \mathrm{~K} / \mathrm{PKB}=$ foszfoinozitid-3 kináz/protein kináz $\mathrm{B}$ (phosphoinositide-3-kinase/protein kinase $B) ; \mathrm{PI}(4,5) \mathrm{P}_{2}=$ foszfatidilinozitol-4,5-biszfoszfát (phosphatidylinositol (4,5)-bisphosphate); $\mathrm{PI}(3,4,5) \mathrm{P}_{3}=$ foszfatidilinozitol-3,4,5-triszfoszfát (phosphatidylinositol $(3,4,5)$-trisphosphate); $\mathrm{PKC}=$ protein kináz C (protein $k i$ nase C); PLCG2 = foszfolipáz C gamma 2 (phospholipase $C-\gamma-2$ ); PFS = progressziómentes túlélés (progression-free survival); PTEN = foszfatáz és tenzin homológ (phosphatase and tensin homolog); Ras/Raf/MEK/ERK1/2 = mitogén aktiválta protein kináz kaszkád (Ras-Raf-MEK-ERK1/2 cascade); $\mathrm{R}$ = rituximab; $\mathrm{R}-\mathrm{B}=$ rituximab + bendamusztin (rituximab + bendamustine); $\mathrm{R} / \mathrm{R}$ CLL = refrakter/relabáló CLL (relapsed/refractory CLL); S6K = S6 kináz (S6 kinase); SLL = kis limfocitás limfóma (small lymphocytic lymphoma); Syk = lép tirozin kináz (spleen tyrosine kinase); TNFa = tumornekrózis faktor a (tumor necrosis factor a); TP53 = tumorszuppresszor P53 (tumor suppressor P53); unmut-IGHV = mutálatlan IGHV (unmutated IGHV)

A krónikus limfocitás leukémia (CLL) a leggyakoribb felnőttkorban előforduló leukémiatípus a nyugati világban. A CLL-es megbetegedések száma Magyarországon is jelentős, évi 400-450 új eset kerül diagnosztizálásra [1]. Az entitás klinikai megjelenése rendkívül változatos, a bete- gek egyharmada évekig nem igényel kezelést, míg körülbelül ugyanennyi esetben a betegség agresszív lefolyást mutat, gyakori relapszusokkal, terápiás rezisztenciával és rövid túléléssel [2,3]. Ezzel összhangban a leukémiás sejtpopuláció genetikai és egyéb biológiai jellemzői jelentősen eltérhetnek az egyes betegekben, melynek korábban alábecsült mértékét egyre növekvő részletességgel fedik fel az array- és új generációs szekvenáláson (NGS) alapuló vizsgálatok [4-8]. Az egyes betegek között mutatkozó változatosság mellett a CLL terápiájának tervezése során számolni kell a betegekben megjelenő klonális evolúcióval is, mely heterogén CLL-es sejtpopuláció kialakulásához vezethet $[9,10]$. A jelenséget elősegíti a CLL-es sejtek eltérő mikrokörnyezeti feltételekhez való alkalmazkodása a csontvelőben, perifériás vérben és nyirokcsomókban, mely elágazó, komplex szubklonális szerkezetet alakíthat ki [10]. A kezelés megkezdését követően a genetikai eltérések különféle együttes előfordulásai egymástól eltérő szelekciós előnyt nyújthatnak az egyes sejtcsoportoknak, a terápiával szemben leginkább ellenálló sejtek jelentős térnyerése pedig az alkalmazott kezelés hatékonyságának csökkenéséhez, végső soron klinikailag megjelenő terápiás rezisztenciához vezethet $[11,12]$.

A CLL általában már korai stádiumban felismerésre kerül, sokszor rutin vérképvizsgálat során észlelt limfocitózis jelzi a betegséget. A kezelés azonnali megindítása nem minden esetben indokolt, tünetmentesség mellett csupán a beteg követése és megfigyelése javasolt („watch and wait”). Klinikai tünetek, úgymint fogyás, láz, éjszakai izzadás, nyirokcsomó-máj-lép-megnagyobbodás vagy anémia és trombocitopénia megjelenését követően ajánlott a terápia elindítása [13]. A betegség kezelését korábban kizárólag a kevéssé szelektív, számos mellékhatással járó kemoterápia jelentette. Helyét a 2000-es évektől a jóval hatékonyabb citotoxikus szerek (klorambucil, fludarabin, ciklofoszfamid) és CD20 antigén elleni antitestekből (rituximab, ofatumumab és az új generációs obinutuzumab) álló kemo-immunoterápia vette át. A német CLL munkacsoport (German CLL Study Group) által 2003 és 2007 között végzett CLL8 klinikai tanulmányban például a fludarabin, ciklofoszfamid és rituximab (FCR) kombinációját (kemo-immunoterápia) a fludarabin-ciklofoszfamid kombinációnál (kemoterápia) hatékonyabbnak találták első vonalbeli kezelésként alkalmazva, hosszabb progressziómentes túléléshez (progression free survival, $P F S$ ), bizonyos genetikai alcsoportoknál pedig hosszabb teljes túléléshez (overall survival, OS) is vezetve [14, 15]. A kemo-immunoterápia napjainkban is fontos szerepet tölt be a CLL kezelésében, leginkább olyan kezeletlen, fiatal fit betegeknél alkalmazzák sikerrel, akik standard fluoreszcencia in situ hibridizációs (FISH) státusszal (normál eredmény, $13 q$ deléció, illetve 12-es triszómia), illetve mutált immunglobulin nehézlánc variábilis génszegmenssel (m-IGHV, mutated IGHV) rendelkeznek [16]. IGHVmutáció-negatív betegségben azonban a magas remissziós ráta ellenére a hatás rendszerint nem hosszú életű, mely újabb kezeléseket tesz szükségessé. 
A CLL célzott terápiás gyógyszereként 2014-ben került bevezetésre a Bruton-féle tirozin kináz- (BTK-) gátló ibrutinib, mely forradalmasította a refrakter/relabáló betegek kezelését [17]. Ibrutinibbel a magas kockázatú, rossz prognózisú betegeknél, mint amilyen a 17 p deléciót vagy TP53-mutációt (összefoglalóan TP53-defektust) hordozók, vagy a mutálatlan IGHV-vel (unmutated IGHV, unmut-IGHV) rendelkezők, első vonalban 70-90\%-os teljes válaszadási arány (overall response rate, ORR) érhető el $[18,19]$. Az ibrutinib megjelenését szorosan követve további célzott terápiák is elérhetővé váltak, mint a foszfatidilinozitol-3-kináz- (PI3K-) gátló idelalisib-rituximab [20], a szintén BTK-gátló acalabrutinib [21], az antiapoptotikus BCL2-gátló venetoclax [22] vagy az egyelőre klinikai vizsgálatokban alkalmazott lép tirozin kináz- (spleen tyrosine kinase, Syk-) gátló fostamatinib [23] és entosplenitinib [24].

\section{A B-sejtreceptor jelátviteli útvonal szerepe a CLL patogenezisében}

A B-sejtreceptor (BCR) jelátviteli útvonal kulcsszerepet tölt be a B-sejtfejlődés egyes szakaszaiban, aktív müködése szükséges a legtöbb B-sejt eredetű malignitás kifejlődéséhez és progressziójához. A BCR-hez kapcsolódó jelátvitel CLL-ben való folyamatos aktivitása miatt, mely föként az IGHV-mutáció negatív esetekben kifejezett, az útvonal komponenseinek gátlása ígéretes terápiás lehetőségeket kínál, ezzel összhangban a közelmúltban bevezetett célzott terápiák többsége ebbe a jelátviteli útvonalba avatkozik be.

A BCR útvonal a B-limfocitákon elhelyezkedő transzmembrán B-sejt receptorokról indul. A receptor egy sejtfelszíni, nehéz és könnyü láncokból álló immunglobulin komplexből és az ahhoz kapcsolódó, intracelluláris CD79a/b heterodimerekből (immunglobulin a és $\beta$ ) épül

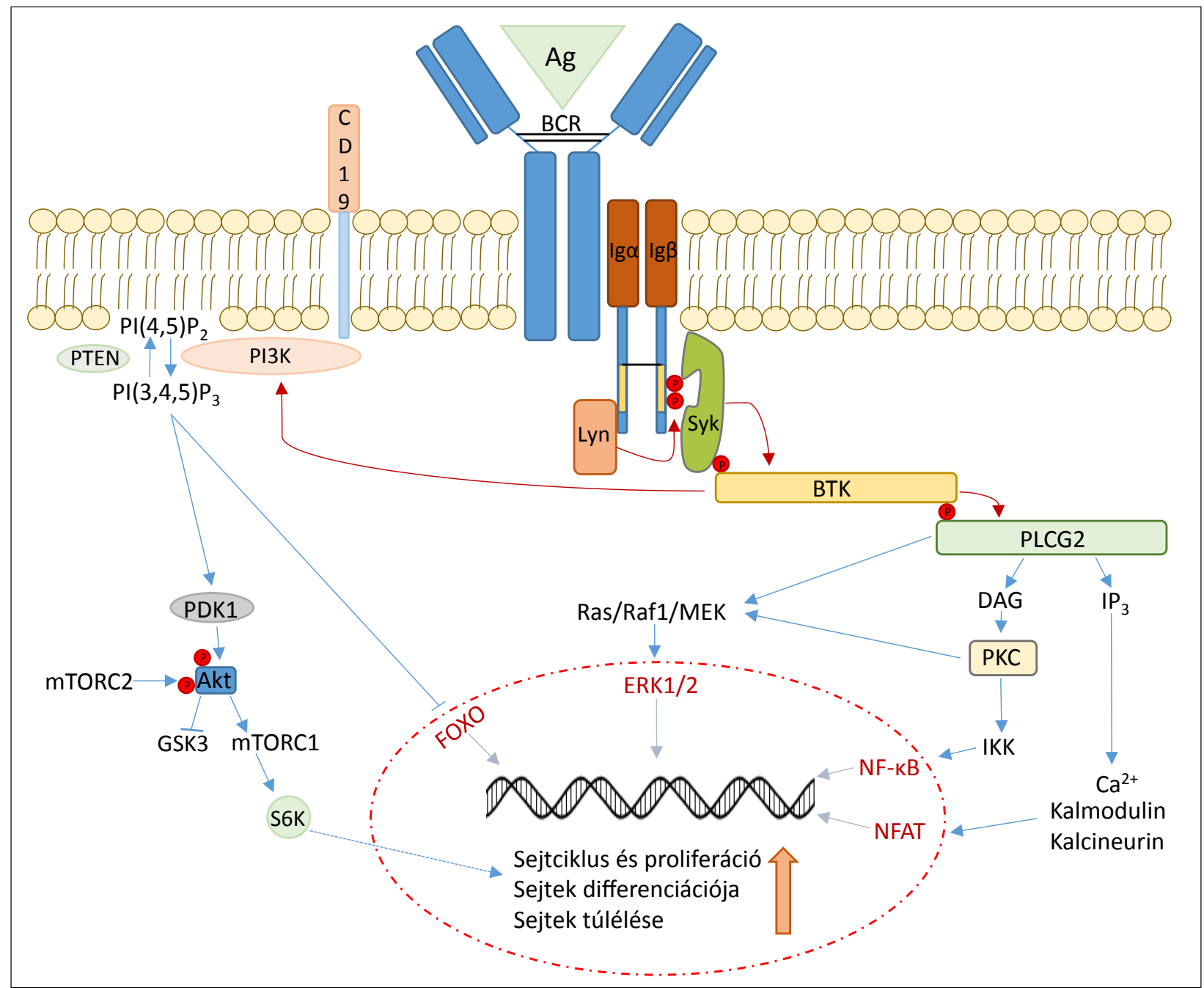

1. ábra. A BCR jelátviteli útvonal kiemelt komponensei és szerepük a krónikus limfocitás leukémia kialakulásában. Antigén inger hatására a BCR jelátviteli út aktiválódik, és elindítja a BTK-PLCG2, PI3K/PKB-Akt-mTOR és MAPK kaszkádokat. A jelet ezután másodlagos hírvivők és transzkripciós faktorok továbbítják a sejtmagba, ahol a sejtciklust, proliferációt, differenciációt és túlélést szabályozó változások következnek be. CLL-ben a BCR útvonal konstitutív, fokozott aktivációja figyelhető meg, ami a leukémiás sejtek túlzott mértékű proliferációját, apoptózisának gátlását, kontrollálatlan túlélését eredményezi 
fel. Külső jelre történő aktivációt követően a Src kinázok, melyek közül B-sejtekben a $L c k /$ Yes novel tirozin-kináz dominál, foszforilálják a CD79a/b citoplazmatikus nyúlványán található immunoreceptor tirozin alapú aktivációs motívumokat, mely lehetővé teszi a Syk enzim kapcsolódását és aktiválódását [25-27]. A jelet ezt követően egy $B$ cell linker proteinből és a hozzá asszociált adapterfehérjékből felépülő komplex, úgynevezett szignaloszóma továbbítja a BTK, illetve annak szubsztrátja, a foszfolipázC-gamma 2 (PLCG2) irányába. A PLCG2 a plazmamembránban található foszfoinozitid-4,5-biszfoszfátot hasítja inozitol-1,4,5-triszfoszfátra $\left(\mathrm{IP}_{3}\right)$ és diacil-glicerinre (DAG) $[27,28] . \mathrm{Az} \mathrm{IP}_{3}$ az endoplazmás retikulum $\mathrm{IP}_{3}$ receptorához kötve a sejtek citoplazmájában növeli a $\mathrm{Ca}^{2+}$-szintet, a DAG pedig aktivátora a protein kináz C-nek (PKC). A BTK, a PKC, valamint a BCR jel hatására szintén aktiválódó foszfoinozitid-3 kináz/protein kináz $\mathrm{B}$ (PI3K/PKB) - Akt tengely számos túlélést befolyásoló úttal áll kapcsolatban, mint például a mitogén aktiválta protein kináz (MAPK) kaszkád (Ras/Raf/MEK/ ERK1/2), a nukleáris faktor kappa B (NF- $\mathrm{B}$ ) és a nuclear factor of activated T-cells (NFAT) útvonalak [27] (1. ábra). A BCR jelátvitel aktivációja így hatással van a B-sejtek túlélésére, szabályozza azok proliferációját, differenciálódását és apoptózisát [29-31]. A fent említett utaknak emellett szerepe van az integrinek aktivációjában, továbbá a CLL-sejtek kemokinfüggő migrációjában is.

\section{Az ibrutinibkezelés mechanizmusa}

Az elmúlt években törzskönyvezett, új célzott terápiákat biztosító molekulák közül az eddig legtöbbet alkalmazott, hatásában, mellékhatásaiban legjobban ismert gyógyszer az ibrutinib, kereskedelmi nevén Imbruvica ${ }^{\circledR}$. Az ibrutinib egy orálisan adható kismolekula, mely a BTK enzimhez irreverzibilis módon kapcsolódva gátolja annak müködését. Strukturális szempontból a BTK egy 5 doménből álló, 76 kilodalton tömegü fehérje, melynek tirozin kináz doménjében, a 481-es pozícióban elhelyezkedő cisztein aminosavhoz (Cys481) kovalens módon képes kapcsolódni az ibrutinib, megakadályozva ezzel az enzim müködéséhez alapvetően szükséges ATP kötődését, ezáltal a BTK autofoszforilációját [32]. Az ibrutinib rövid felezési idejü gyógyszer (4-13 óra), BTK-hoz való irreverzibilis kapcsolódása azonban lehetővé teszi gátló hatásának fenntartását 24 órán keresztül [33]. Ennek köszönhetően a gyógyszer szedése szempontjából kedvező, napi egyszeri adagolás alkalmazható CLL-es betegeknél, $420 \mathrm{mg}$ dózissal.

\section{A BTK-gátlás közvetlen hatása a CLL sejtekre}

Az ibrutinib a BTK blokkolásával a jelátviteli útvonalban attól downstream elhelyezkedő PLCG2-t is indirekt módon gátolja, valamint csökkenti az extracelluláris jel által regulált kináz (ERK) és a $\mathrm{PI}$ KK/PKB enzimek foszforilációját, illetve az NF-кB1 intracelluláris expresszióját [34,

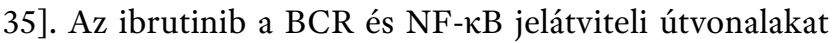
a CLL-es sejtekben rövid idő alatt és tartósan gátolja, hatását kifejti a perifériás vérben, nyirokcsomóban, illetve csontvelőben is [35]. A PI3K/PKB és az NF- $\kappa \mathrm{B}$ útvonalak blokkolásával a MAPK kaszkád is gátlás alá kerül, így az ibrutinib csökkenti a CLL sejtek aktivációját és proliferációját in vitro és in vivo egyaránt [31, 33, 35, 36].

\section{Hatás a környezet sejtjeire}

Az ibrutinibkezelés hatással van az immunsejtekre és a CLL sejtek környezetére is, korlátozva a „mikrokörnyezet" CLL sejteket védő hatását, ezzel elősegítve a leukémiás sejtek pusztulását [33, 36, 37]. Az ibrutinib számos, CLL-ben emelkedett szérumszintet mutató gyulladásos citokin mennyiségét is csökkenti, úgymint az interleukin-1 receptor antagonista-1, az interleukin-10, a tumornekrózis faktor a és az interferon a szintjét [38]. A leukémiás sejtek ibrutinib hatására a limfociták hazatérésében (homing) szerepet játszó CXCL12 és CXCL13 (kemokin (C-X-C motívum) ligand 12 és 13) kemokinekre mérsékelt kemotaxis választ adnak [38]. A CXCR4-CXCL12 tengely gátlása miatt a kezelés elején, többnyire annak első hónapjában a „haza nem találó”, nyirokcsomókból „kiszabaduló” limfociták a perifériás vérben dúsulnak fel. Ennek következtében a nyirokcsomók mérete csökken, míg a perifériás vérben átmeneti limfocitózis figyelhető meg $[25,36]$. Az ibrutinib nemcsak a T-sejtek és plazmasejtek kivételével szinte minden hemopoetikus sejtben expresszálódó BTK-t gátolja, hanem további közel 20 kinázt is, mint például a T-sejtek és természetes ölősejtek (natural killer, $N K$ ) által expresszált IL-2-indukált-Tsejt kinázt (ITK) [39]. A gyógyszer az ITK-hoz irreverzibilisen kötve gátolja a T-sejtek immunfunkcióját, ezáltal csökkentve azok aktivációját és proliferációját CLL-es betegekben [37, 39]. A fenti példák mutatják, hogy a BTK enzimre, illetve a leukémiás B-sejtekre korlátozódó kutatások nem elegendőek az ibrutinibkezelés CLL-ben mutatkozó hatásmechanizmusának kiterjedt feltérképezéséhez, a hemopoetikus sejtek átfogó analízise elengedhetetlen a terápia kapcsán bekövetkező funkcionális változások részletes feltárásához.

\section{Az ibrutinibkezelés megkezdése}

$\mathrm{Az}$ ibrutinib hazánkban harmadvonalbeli célzott kezelésként alkalmazható relabáló vagy kemo-immunoterápia refrakter CLL-es (R/R CLL) betegeknél [17, 40, 41], illetve első vonalban adható rossz prognózisú, TP53-defektust hordozó betegeknek [41-43]. A TP53 státusz felmérése ezért minden egyes terápiás vonal megkezdése előtt erősen ajánlott, mivel abnormalitást hordozó betegeknél kemo- és kemo-immunoterápiával is csupán alacsony terápiás válasz érhető el, 1,0-1,5 éves progressziómentes és 2,5-3,0 éves teljes túléléssel [44, 45]. Az eljárás tipikusan magában foglalja a 17 p13 kromoszómális régiót érintő 
deléciók kimutatását FISH-sel, illetve a TP53 génben jelentkező mutációk feltérképezését Sanger-szekvenálással vagy NGS-sel [46-49]. A TP53 deléciót hordozó betegek 80-90\%-ában fordul elő TP53-mutáció is a kópiaszámeltérés által nem érintett allélon, míg a mutációt hordozó betegek 50-70\%-ában jelentkezik monoallélikus deléció [50, 51]. Hagyományos módszerekkel vizsgálva diagnóziskor a betegek 5-10\%-ában mutatható ki TP53 defektus, míg a kemo-immunoterápiát követően relabáló betegek körében ez az érték 35-40\% [52, 53]. Az arány tovább növekszik Sanger-szekvenálásnál nagyobb érzékenységü NGS módszerek alkalmazásával, melyekkel 10\%-os vagy akár annál alacsonyabb variáns allél frekvenciával rendelkező mutációk is kimutathatók [13]. A közelmúltban bevezetett BCR jelátviteli útvonal, illetve BCL2-gátló kezelések, köztük az ibrutinib is, jelentős áttörést hoztak a TP53 defektust hordozó betegek kezelésében, ezzel növelve a TP53 státusz meghatározásának fontosságát és valamelyest csökkentve a TP53-aberrációk prediktív jelentőségét, legalábbis az új terápiás lehetőségek fényében $[54,55]$.

A CLL-es betegek ibrutinibkezelését számos klinikai tanulmány vizsgálta, melyek közül a legfontosabbakat az 1. táblázat foglalja össze. CLL-terápián kívül az ibrutinibet további malignus hematológiai betegségek kezeléséhez is alkalmazzák, mint például a felnőttkori $R / R$ köpenysejtes limfóma, a Waldenström-macroglobulinémia, vagy az R/R marginális zóna limfóma [68-70].

\section{Az ibrutinibrezisztencia klinikai megjelenése}

A látványos sikerek mellett az ibrutinibterápiában részesülő CLL-es betegek egy részénél rezisztencia alakul ki a kezelés során. Az eddigi leghosszabb követési idővel Byrd és mtsai közöltek túlélési adatokat, 30 hónapos kezelést követően 96\%-os, illetve 69\%-os PFS-ről számoltak be kezeletlen, illetve R/R betegeknél [71], a megfelelő értékek 5 éves követési idő után $92 \%$-nak és $44 \%$-nak bizonyultak [72], míg a 7 éves becsült értékek $80 \%$-ot, illetve 32\%-ot mutattak [73]. A TP53 deléció jelenléte, illetve magasabb számú $(\geq 4)$ korábbi kezelési vonal alkalmazása rövidebb PFS-sel társult az R/R betegek között [72]. Az ibrutinibkezelés hatékonyságának rezisztenciával összefüggő hanyatlása a laboratóriumi értékek romlásán keresztül klinikai relapszushoz vezet. Progrediáló betegségre utaló jel egy újonnan megnagyobbodó nyirokcsomó vagy egy korábban is érintett nyirokcsomó több mint 50\%-kal való megnagyobbodása; fokozódó hepatoszplenomegália $(>50 \%)$; progresszív limfocitózis ( $>50 \%$ vagy $>5 \times 10^{9}$ $\mathrm{G} / \mathrm{l}$ ); citopénia (neutropénia, anémia, trombocitopénia); vagy a betegség agresszív transzformációja (Richter-szindróma) [13]. Richter-transzformáció során az esetek nagy többségében terápiarezisztens, az alapbetegséggel klonális kapcsolatban álló diffúz nagy B-sejtes limfóma vagy prolimfocitás leukémia fejlődik ki, de további malignitások is megjelenhetnek, mint például Hodgkin-limfóma, plaz- mablasztos limfóma, kevert B- és T-sejtes limfóma vagy perifériás T-sejtes limfóma [74, 75]. Richter-transzformáció leginkább a kezelés első két évében fordul elő, míg transzformáció nélküli CLL progresszió tipikusan hoszszabb idő elteltével jelentkezik, a kezelés első évében nem jellemző. $\mathrm{Az}$ ibrutinibbel kezelt, relabáló CLL-es betegeknél a medián túlélés legjobb esetben is kevesebb mint 2 év, sok esetben kevesebb mint 6 hónap [74, 76].

\section{Ibrutinibrezisztenciát kísérő genetikai változások}

Az ibrutinibkezelést követően progresszív CLL-t mutató betegek körülbelül 80-85\%-ában mutatható ki a BTK és/ vagy a $P L C G 2$ gén mutációja, míg Richter-transzformáció esetén ez az arány jelenlegi ismereteink szerint alacsonyabbnak tünik [77, 78]. Az ezzel kapcsolatos első adatokat Woyach és mtsai közölték, akik 6 ibrutinibkezelés mellett relabáló beteg perifériás mintáját vizsgálták exomszekvenálással. A szerzők 5 betegnél a $B T K$ tirozin-kináz (TK) doménjében elhelyezkedő, 481-es számú cisztein aminosav szerinre való cseréjét (C481S) azonosították [78]. A gyógyszerkötő helyet érintő mutáció hatására csökken az ibrutinib BTK iránti affinitása, irreverzibilisről reverzibilisre változtatva a kötés természetét, mely mérsékelt $B T K$-gátláshoz vezet [74, 78, 79]. A $B T K$ génben azóta számos további, eltérő lokalizációjú mutációt azonosítottak ibrutinibkezelés mellett. Egy közelmúltbeli tanulmányunkban 20 CLL-es beteg sorozat mintáit vizsgáltuk célzott mélyszekvenálással, melynek során négy korábban ismeretlen, R28S, G164D, R490H, illetve Q516K aminosavcserékhez vezető, ibrutinibkezeléshez asszociáltan megjelenő mutációt azonosítottunk. Ezek közül az R490H és a Q516K, hasonlóan a C481S-hez, a BTK-gátlás hatékonysága szempontjából kulcsfontosságú TK doménben mutatkozott (Gángó és mtsai, doi: 10.1002/ijc.32502).

A BTK közvetlen szubsztrátját kódoló PLCG2 gén funkciónyerő mutációinak következtében a BCR jelátviteli útvonal downstream szakaszán még blokkolt BTKaktivitás mellett is folyamatos jeltovábbítás biztosított, melynek hatására az ibrutinibkezelés hatékony gyógyszerkapcsolódás esetén sem éri el végső célját [45, 54]. A $P L C G 2$ génben napjainkig azonosított mutációk a $B T K-$ mutációkhoz képest nagyobb mértékü változatosságot mutatnak, lokalizációjuk azonban nem véletlenszerü, eloszlásuk emelkedett sűrűséget mutat, többek között a gén Src homológ 2 (SH2) autoinhibitor doménjében [45]. $\mathrm{Az}$ ebben a régióban megjelenő mutációk, mint például a P664S, R665W vagy $\mathrm{S} 707 \mathrm{Y} / \mathrm{F} / \mathrm{P}$ aminosavcseréket eredményező variánsok, az átíródott fehérje fokozott aktivitását idézik elő [80]. Az SH2 doménen kívül megjelenő mutációk többségénél az ibrutinibkezelésre gyakorolt hatás kiderítéséhez további in vitro és in vivo tanulmányokra lenne szükség, néhány ilyen variáns (pl.: L845F) jelenlétének ibrutinibrezisztenciával való összefüggése azonban már bizonyítást nyert [81]. A fentebb említett 


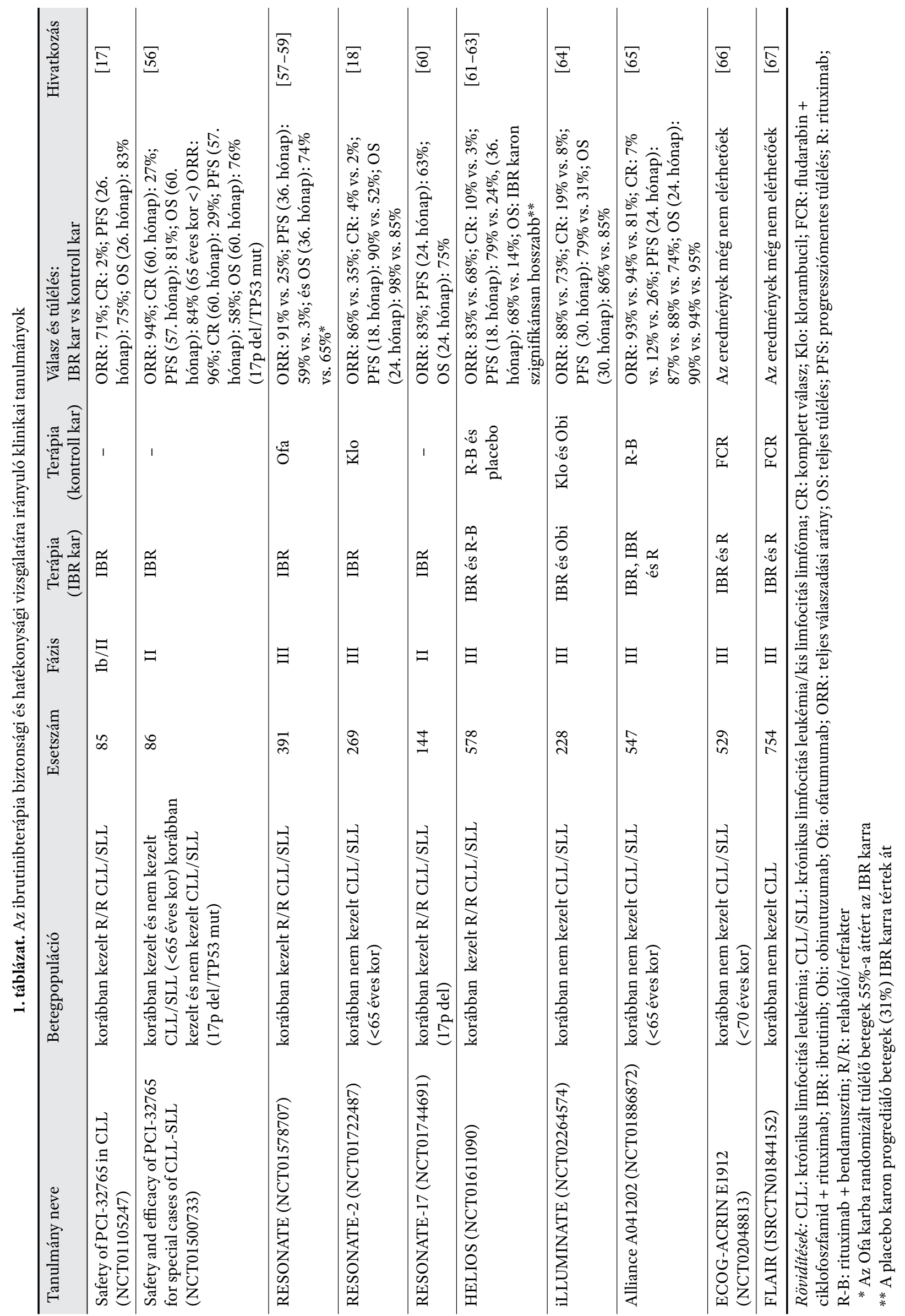



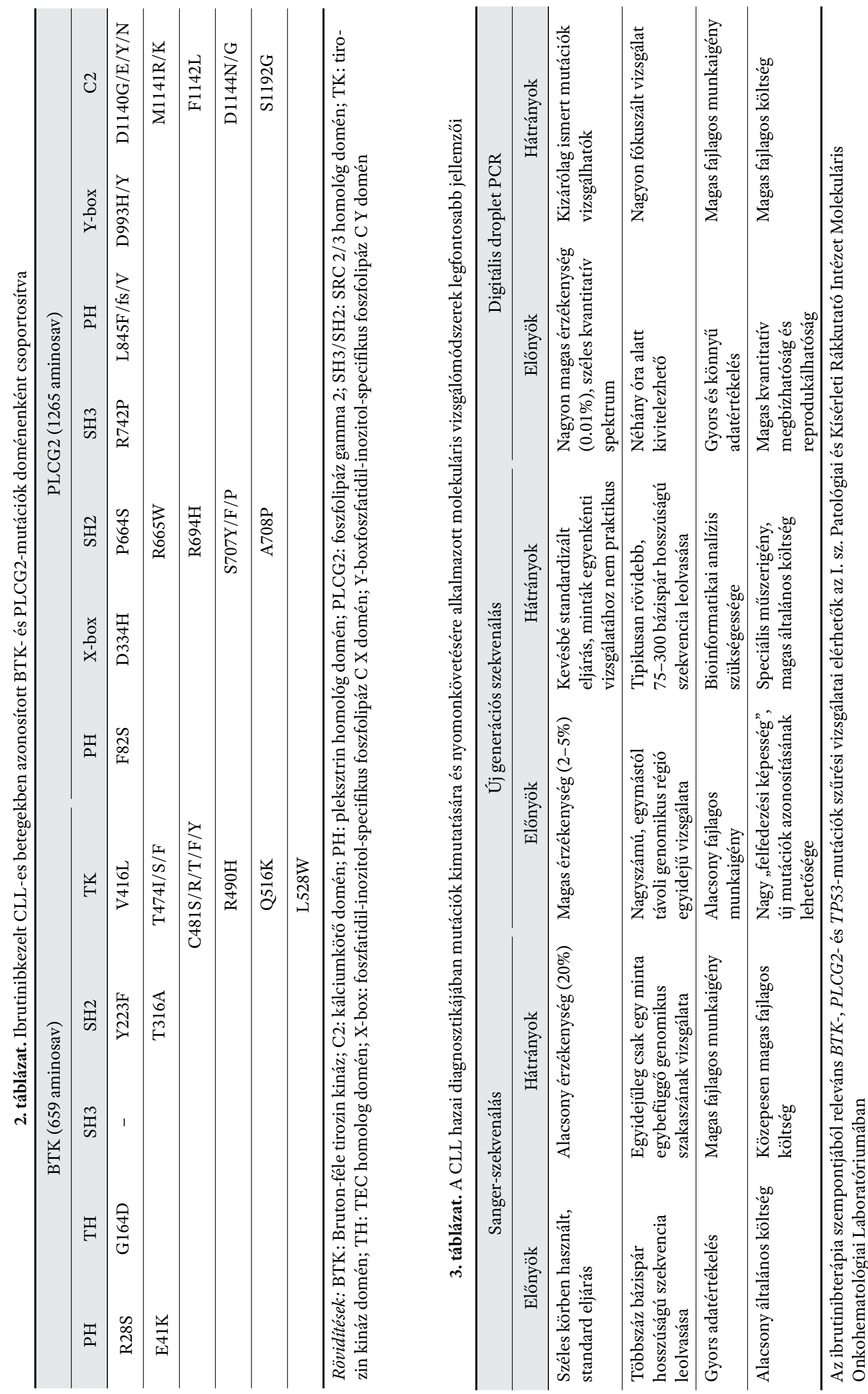
tanulmányunkban korábban ismeretlen, ibrutinibkezelés során megjelenő variánsokat azonosítottunk a PLCG2 génben is, melyek közül az egyik mutáció a gén $\mathrm{SH} 2$ doménjében idézett elő R694H aminosavcserét (2. táblázat).

A BTK és PLCG2 gének mutációi mellett további genetikai eltérések is azonosításra kerültek ibrutinibrezisztens
CLL-es betegekben, úgymint a 8-as kromoszóma rövid karjának deléciói vagy a $P C L O$ gén mutációi $[11,82]$. Bár ezek az aberrációk visszatérő módon, több betegben is kimutathatók voltak, az ibrutinibrezisztencia kialakításában játszott feltételezett szerepük tisztázása további alapos vizsgálatokat igényel.

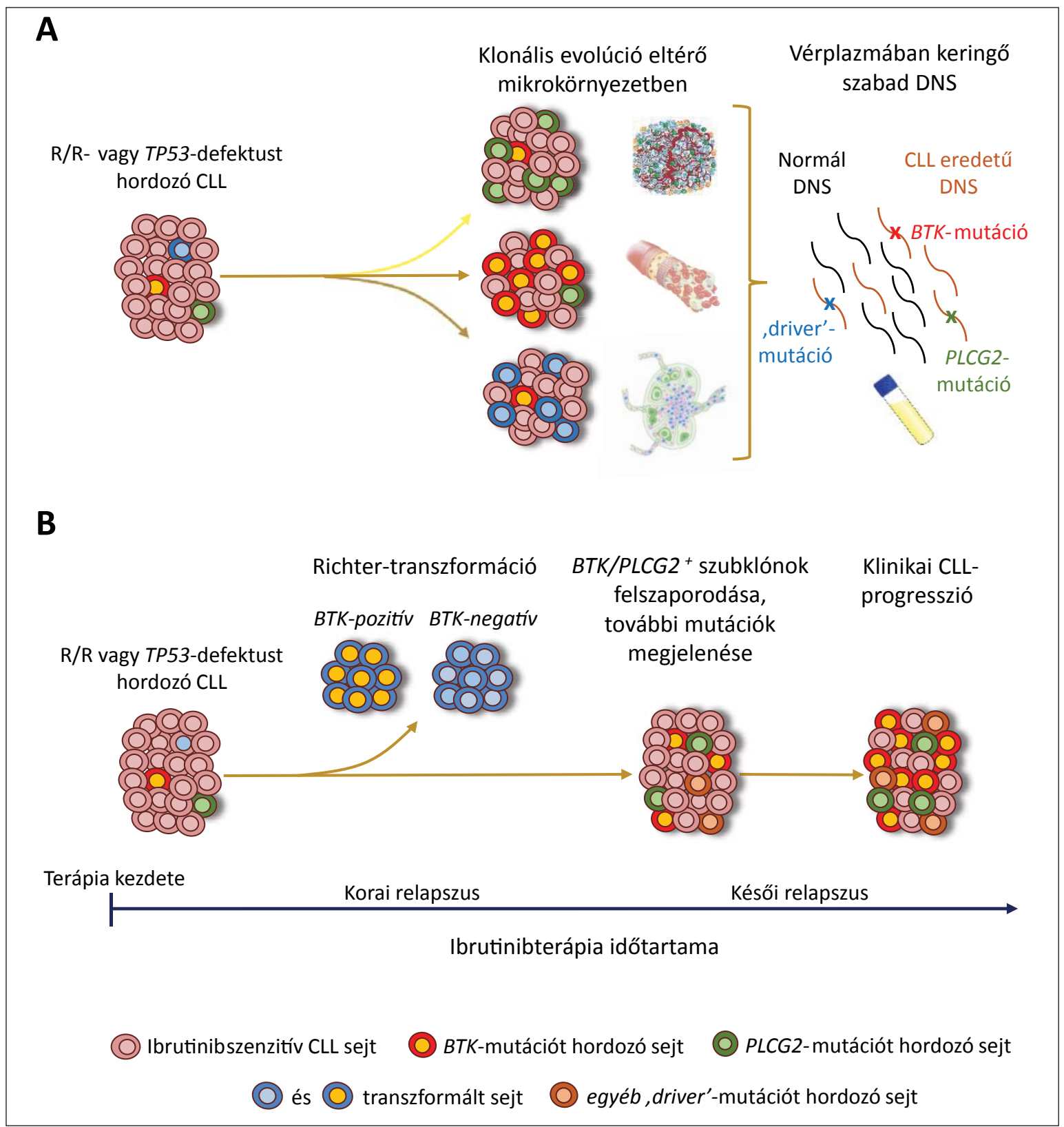

2. ábra. Krónikus limfocitás leukémia ibrutinibkezelés hatására bekövetkező klonális evolúciója térben és időben. (A) A csontvelő, perifériás vér és az érintett nyirokcsomók egymástól eltérő mikrokörnyezetet biztosítanak a leukémiás sejtek számára, ami különböző genetikai háttérrel rendelkező szubklónok térnyerésének kedvez. Az ibrutinibterápia domináns szelekciós nyomása miatt ugyanakkor az eltérő szubklónok által hordozott különféle rezisztenciamutációk többsége ugyanazt a (BCR) jelátviteli útvonalat befolyásolja. Mivel lokalizációtól függetlenül mindegyik szubklón bocsát ki sejtmentes szabad DNS-t a vérkeringésbe, a vérplazma keringő DNS-frakciójának érzékeny módszerekkel való vizsgálata segítheti a terápiarezisztenciához asszociált mutációk átfogó szürését, teljesebb képet adva a betegség progresszióját kísérő heterogén genetikai változásokról. (B) Az ibrutinibterápia megkezdését követő első 1-2 évben bekövetkező relapszusok oka döntő többségben Richter-transzformáció. A leukémia transzformáció nélküli progressziója jellemzően 18-24 hónap ibrutinibkezelést követően figyelhető meg. A terápiás rezisztencia kialakulásához több különböző, BTK- és/vagy PLCG2-mutációkat hordozó szubklón járulhat hozzá, emellett további driveraberrációk is megjelenhetnek a leukémiás sejtpopulációban. Röviditések: $R / R$ : Refrakter vagy relabáló CLL 


\section{Rezisztenciához társuló genetikai eltérések kimutatása - módszerek és kihívások}

Ibrutinibrezisztenciát mutató CLL-es betegekben a $B T K$ és PLCG2 gének aberrációi érzékeny módszerekkel átlagosan 9-10, de akár 15 hónappal a klinikai relapszus előtt is kimutathatók [83], ami arra enged következtetni, hogy ezeknek a mutációknak a célzott kezelés során történő detektálása és mennyiségi meghatározása várhatóan előre jelezhet egy esetlegesen közelgő relapszust. A mutációk szüréséhez és nyomon követéséhez többféle PCRés DNS-szekvenáláson alapuló technika is használható, az egyes módszerek egymást kiegészítő előnyeit és korlátait figyelembe véve azonban valószínüsíthető, hogy azok kombinált alkalmazása nyújt majd optimális eszköztárat a kezelés hatékonyságának monitorozásához (3. táblázat).

A BTK- és PLCG2-mutációk egyes betegeken belül végzett részletes tér- és időbeli vizsgálata rámutatott arra, hogy a betegség ibrutinibkezelés mellett végbemenő progressziójára is jellemzőek azok az alapvető evolúciós törvényszerűségek, melyeket elsőként Charles Darwin fogalmazott meg a 19. században, fajképződéssel kapcsolatos kutatásai során. Az elmúlt évtizedben a darwini evolúciós folyamatok központi jelentősége számos rosszindulatú hemopoetikus betegség fejlődése, progressziója és terápiás rezisztenciája kapcsán igazolódott [84]. Eszerint a betegség előrehaladását a malignus sejtek felszaporodása nyomán bekövetkező véletlenszerű genetikai diverzifikálódás kíséri, aminek eredményeként létrejön egy olyan heterogén sejtpopuláció, amelyből kiindulva a mikrokörnyezeti tényezőkhöz - jelen esetben az ibrutinibkezeléshez - legjobban alkalmazkodó, terápiarezisztens szubklónok szelekciós előnyt nyernek. E szelekciós folyamat során egymással párhuzamosan több különböző genetikai háttérrel rendelkező sejtcsoport is felszaporodhat, aminek eredményeként elágazó, komplex szubklonális szerkezet alakul ki (2. ábra). Ezzel összhangban Ahn és mtsai ibrutinibkezelés mellett progressziót mutató CLL-es betegek mintáiban aminosavcserét okozó BTKés $P L C G 2$-mutációkat vizsgálva parallel szubklonális evolúcióra utaló mintázatokat figyeltek meg a betegek egy részében [85]. Bár ezeket a szelekciós előnyt biztosító 'driver'-mutációkat a szerzők a betegek korábbi, klinikai progresszió előtt hónapokkal, akár több mint egy évvel vett mintáiban is ki tudták mutatni, a célzott kezelés előtti, illetve az ibrutinibkezelés nagyon korai fázisában vett minták negatívnak bizonyultak az alkalmazott, $10^{-3}$ érzékenységű NGS módszerrel. Korábbi, számítógépes modellezést, illetve $5 \times 10^{-5}$ érzékenységü digitális droplet PCR módszert alkalmazó tanulmányok eredményei azonban arra utalnak, hogy a mutációknak legalább egy része kisméretü pre-leukémiás/leukémiás sejtpopulációkban már az ibrutinibkezelés előtt is jelen kell lennie az egyes betegekben $[82,86]$. Ennek meggyőző bizonyítása azonban még további vizsgálatokat igényel.
A CLL célzott terápiája során nyert monitorozási adatok értelmezésénél fontos figyelembe venni, hogy a perifériás vér kizárólagos vizsgálata csupán korlátozott információt nyújt annak ellenére, hogy leukémiás manifesztációjú kórképet vizsgálunk. A perifériás vérben, nyirokcsomókban, illetve csontvelőben az eltérő mikrokörnyezeti hatások miatt különböző genetikai háttérrel rendelkező pre-leukémiás és leukémiás sejtek nyerhetnek szelekciós előnyt. A CLL térbeli heterogenitásának vizsgálatát nehezíti, hogy az invazív csontvelő- és nyirokcsomó-biopsziás mintavételek a terápiás döntések nagy részének meghozatala előtt jelenleg nem támogatottak a klinikai gyakorlatban. Munkacsoportunk egy ibrutinibkezelés alatt Richter-transzformációt mutató beteg relapszus idején vett nyirokcsomó- és perifériás vérmintáját vizsgálva térben párhuzamos klonális evolúciót figyelt meg, eltérő mutációkat azonosítva a BTK és PLCG2 génekben [10]. Az eredetileg kizárólag eltérő szöveti környezetben detektált mutációk mindegyike kimutatható volt digitális droplet PCR-rel a vérplazmából izolált keringő sejtmentes tumor DNS-frakcióban, mely korábbi adatokkal összhangban demonstrálja, hogy a 'folyadékbiopszia' vizsgálata hatékonyan segítheti az ibrutinibkezelést kísérő genetikai változások felderítését az egyes betegekben [87].

Egyre gyarapodó ismereteink ellenére az ibrutinibrezisztenciát kísérő genetikai változásokkal kapcsolatban még számos fontos kérdés vár megválaszolásra. BTK- és PLCG2-mutációk például olyan betegek egymást követő sorozatmintáiban is következetesen kimutathatók, akik a pozitív mintavételt követően még évekig progressziómentesek. Ebből következően a kizárólag BTK- és PLCG2-mutációk kimutatásán alapuló molekuláris monitorozási stratégiáknak jelenlegi ismereteink szerint alacsony lenne a specificitásuk [88], igaz ennek megítélését a betegek egyre hosszabb idejü nyomon követése módosíthatja a jövőben. Ezenkívül a progresszió idején kimutatott $B T K$ - és $P L C G 2$-mutációk az irodalomban publikált esetek nem elhanyagolható részében csupán alacsony arányban $(<30 \%)$ voltak jelen a vizsgált mintában, ami megkérdőjelezi ezeknek az aberrációknak a meghatározó/ domináns szerepét a terápiás rezisztencia kialakításában, legalábbis a betegek egy részében [77]. Végül, az ibrutinibrezisztens CLL-es betegek 15-20\%-ában nem mutatható ki $B T K$ vagy $P L C G 2$ génmutáció, a mai napig felmerült néhány további genetikai marker szerepének tisztázása pedig még további funkcionális vizsgálatokat igényel (lásd fentebb). Az ibrutinibkezeléshez társuló klonális evolúciós folyamatok alaposabb megértéséhez, az egyes genetikai biomarkerek prediktív erejének pontosabb megítéléséhez, valamint a terápiás rezisztencia hatékony monitorozási stratégiájának kidolgozásához szükség lesz kellőképpen standardizált, érzékeny analitikai módszerekre, továbbá olyan tanulmányokra, melyek az időbeli változások mellett figyelembe veszik a betegség evolúciójának térbeli dimenzióit is. 


\section{Terápiás lehetőségek ibrutinibrezisztencia esetén}

Az ibrutinirezisztencia kialakulását követően standard módon alkalmazható terápiás lehetőségek jelenleg intenzív nemzetközi vizsgálatok tárgyát képezik. Klinikai progresszió esetén az ibrutinibterápia azonnali elhagyása gyors állapotromláshoz vezethet, emiatt ez nem javasolt egészen addig, míg a beteg alternatív kezelési stratégiája nem kerül kidolgozásra, illetve a választott gyógyszer nem válik azonnal elérhetôvé [79]. A jelenleg még korlátozottan rendelkezésre álló ismeretek alapján az ibrutinibkezelés fenntartása Richter-transzformáción átesett, kemo-immunoterápiában részesülő betegeknél is indokolt.

BTK C481-mutáció esetén a BTK ettől eltérő pozíciókon keresztüli gátlása potenciálisan sikeres beavatkozási lehetőséget nyújthat [89-91]. További terápiás lehetőséget kínál a BTK enzim kinázgátlástól eltérő befolyásolása. Hősokkfehérje 90 (heat shock protein 90), HDAC- és XPO1/CRM1-inhibitorokkal végzett korábbi in vitro és in vivo kísérletek például ígéretesnek bizonyultak ibrutinibrezisztencia kezeléséhez [92-94]. BTK- és PLCG2mutációk jelenlétében a $B C R$ jelátviteli útvonal további komponensei gyakran érintetlenek maradnak, így az útvonal BTK-hoz képest felsőbb („upstream”) és alsóbb („downstream”) szakaszainak támadása szintén sikeres gátlást eredményezhet, melyre példaként szolgálnak a Syk- és PKC $\beta$-inhibitorokkal nyert eredmények [24, 95, 96]. Az ibrutinibrezisztenciát kísérő fokozott PI3Kaktivitás miatt idelalisib-, duvelisib- és további PI3K-gátló terápiák is elvileg alkalmazhatók ibrutinibrezisztens betegeknél, akár C481-mutáció jelenlétében is, ugyanakkor a kezeléssel járó kedvezőtlen toxicitási profil korlátozza ezeknek a gyógyszereknek a széles körű használatát [97, 98].

A BCL2 antagonista venetoclax az egyik legígéretesebb célzott terápia, mely ibrutinibrezisztens CLL-es betegek kezeléséhez eddig kipróbálásra került. Ezt a Magyarországon is törzskönyvezett gyógyszert korábban ibrutinibbel kezelt, CLL-progressziót mutató betegeknél monoterápiaként alkalmazva 65\%-os ORR-t értek el, a terápiás választ mutatók $88 \%$-ánál legalább 12 hónapig tartó válasszal [99]. A BTK- és/vagy PLCG2-mutációt hordozó, ibrutinibrezisztens betegek vonatkozásában 71\%-os ORR volt megfigyelhető. Az ibrutinib- és venetoclaxterápiáknak nem csak egymást követő alkalmazása ígéretes, a két gyógyszer kombinált kezelésként is biztató eredményeket hozott R/R CLL és magas kockázatú kezeletlen betegeknél [100, 101].

$\mathrm{Az}$ ibrutinibrezisztencia leküzdéséhez a fentieken túl megfontolásra kerülhetnek egyéb alternatív terápiás lehetőségek is, úgymint az allogén őssejt-transzplantáció vagy a kiméra antigén receptor T-sejtterápia. A transzplantációs lehetőség természetesen csak azok számára lehet elérhető, akiknél rendelkezésre áll megfelelő donor, és más terápiás eszközökkel remisszió érhető el náluk.

\section{Következtetés}

Az ibrutinibterápia forradalmasította a rossz prognózisú TP53-pozitív, illetve R/R CLL-ben szenvedő betegek kezelését. A látványos klinikai sikerek mellett azonban a kezelt betegek egy részénél rezisztencia alakul ki, melynek esélye a kezelési idő előre haladtával fokozatosan emelkedik. A jelenség hátterében álló molekuláris mechanizmusok egyre pontosabb feltérképezése és megértése várhatóan segítheti majd a laboratóriumi és klinikai relapszus elörejelzését, illetve nagymértékben hozzájárulhat alternatív kezelési stratégiák kidolgozásához, azok klinikai döntéshozatalban való optimális megválasztásához. Munkacsoportunk ezért kiemelt hangsúlyt fektet az ibrutinibkezelést kísérő biológiai folyamatok kutatására, a lehetséges rezisztenciamechanizmusok alapos feltárására, illetve a hazai mintavételi protokollokhoz alkalmazkodó, informatív monitorozási stratégia kidolgozására.

Nyilatkozat: A kézirat más folyóiratban korábban nem jelent meg, és máshova beküldésre nem került. A levelező szerző elolvasta a Hematológia-Transzfuziológia szerzői útmutatóját.

Anyagi támogatás: A közlemény megírásához kapcsolódó munkát a Nemzeti Kutatási, Fejlesztési és Innovációs Hivatal - NKFIH, K_16-119950, NVKP_16-1-2016-0004 és KH_17-126718 pályázatai, valamint a Magyar Tudományos Akadémia Lendület Programjának LP95021 pályázata és Bolyai János Kutatási Ösztöndíj programja (BO/00320/18/5) támogatta. További támogatást nyújtott az Emberi Erőforrások Minisztériumának ÚNKP-18-4SE-62 kódszámú Bolyai+ Új Nemzeti Kiválósági Programja és Felsőoktatási Intézményi Kiválósági Programja, a Semmelweis Egyetem molekuláris biológia tématerületi programjának keretében.

Érdekeltségek: A szerzőknek a közleményhez kapcsolódó közvetlen érdekeltségeik nincsenek.

Szerzöi munkamegosztás: B. Cs. és A. D.: A közlemény struktúrájának megtervezése. A. D., M. Z., K. R. , B. A., I. S., B. Cs. és A. D.: a kézirat elkészítése. A cikk végleges változatát valamennyi szerző elolvasta és jóváhagyta.

\section{Irodalom}

[1] Losonczy H, Méhes G. B-cell chronic lymphocytic leukemia/small lymphocytic lymphoma. In: Matolcsy A, Udvardy M, Kopper L. (ed.) Atlas of hematological diseases. [B-sejtes krónikus lymphocytás leukaemia/kis lymphocytás lymphoma. In: Matolcsy A, Udvardy M, Kopper L. (szerk.) Hematológiai betegségek atlasza.] Medicina Könyvkiadó Rt., Budapest, 2006; pp. 223-230. [Hungarian]

[2] Dohner H, Stilgenbauer S, Benner A, et al. Genomic aberrations and survival in chronic lymphocytic leukemia. N Engl J Med. 2000; 343: 1910-1916.

[3] Brown JR. How I treat CLL patients with ibrutinib. Blood 2018; 131: 379-386. 
[4] Landau DA, Tausch E, Taylor-Weiner AN, et al. Mutations driving CLL and their evolution in progression and relapse. Nature 2015; 526: 525-530.

[5] Puente XS, Bea S, Valdes-Mas R, et al. Non-coding recurrent mutations in chronic lymphocytic leukaemia. Nature 2015; 526: 519524.

[6] Rendeiro AF, Schmidl C, Strefford JC, et al. Chromatin accessibility maps of chronic lymphocytic leukaemia identify subtype-specific epigenome signatures and transcription regulatory networks. Nat Commun. 2016; 7: 11938.

[7] Yeh YY, Ozer HG, Lehman AM, et al. Characterization of CLL exosomes reveals a distinct microRNA signature and enhanced secretion by activation of BCR signaling. Blood 2015; 125: 32973305.

[8] Oakes CC, Claus R, Gu L, et al. Evolution of DNA methylation is linked to genetic aberrations in chronic lymphocytic leukemia. Cancer Discov. 2014; 4: 348-361.

[9] Landau DA, Sun C, Rosebrock D, et al. The evolutionary landscape of chronic lymphocytic leukemia treated with ibrutinib targeted therapy. Nat Commun. 2017; 8: 2185.

[10] Kiss R, Alpár D, Gángó A, et al. Spatial clonal evolution leading to ibrutinib resistance and disease progression in chronic lymphocytic leukemia. Haematologica 2019; 104: e38-e41.

[11] Kadri S, Lee J, Fitzpatrick C, et al. Clonal evolution underlying leukemia progression and Richter transformation in patients with ibrutinib-relapsed CLL. Blood Adv. 2017; 1: 715-727.

[12] Leeksma AC, Taylor J, Wu B, et al. Clonal diversity predicts adverse outcome in chronic lymphocytic leukemia. Leukemia 2019; 33: 390-402.

[13] Hallek M, Cheson BD, Catovsky D, et al. iwCLL guidelines for diagnosis, indications for treatment, response assessment, and supportive management of CLL. Blood 2018; 131: 2745-2760.

[14] Fischer K, Bahlo J, Fink AM, et al. Long-term remissions after FCR chemoimmunotherapy in previously untreated patients with CLL: updated results of the CLL8 trial. Blood 2016; 127: 208215.

[15] Hallek M, Fischer K, Fingerle-Rowson G, et al. Addition of rituximab to fludarabine and cyclophosphamide in patients with chronic lymphocytic leukaemia: a randomised, open-label, phase 3 trial. Lancet 2010; 376: 1164-1174.

[16] Parikh SA. Chronic lymphocytic leukemia treatment algorithm 2018. Blood Cancer J. 2018; 8: 93.

[17] Byrd JC, Furman RR, Coutre SE, et al. Targeting BTK with ibrutinib in relapsed chronic lymphocytic leukemia. N Engl J Med. 2013; 369: 32-42.

[18] Burger JA, Tedeschi A, Barr PM, et al. Ibrutinib as initial therapy for patients with chronic lymphocytic leukemia. N Engl J Med. 2015; 373: 2425-2437.

[19] Farooqui MZ, Valdez J, Martyr S, et al. Ibrutinib for previously untreated and relapsed or refractory chronic lymphocytic leukaemia with TP53 aberrations: a phase 2, single-arm trial. Lancet Oncol. 2015; 16: 169-176.

[20] Furman RR, Sharman JP, Coutre SE, et al. Idelalisib and rituximab in relapsed chronic lymphocytic leukemia. N Engl J Med. 2014; 370: 997-1007.

[21] Byrd JC, Harrington B, O’Brien S, et al. Acalabrutinib (ACP-196) in relapsed chronic lymphocytic leukemia. N Engl J Med. 2016; 374: 323-332.

[22] Roberts AW, Davids MS, Pagel JM, et al. Targeting BCL2 with venetoclax in relapsed chronic lymphocytic leukemia. N Engl J Med. 2016; 374: 311-322.

[23] Herman SEM, Barr PM, McAuley EM, et al. Fostamatinib inhibits B-cell receptor signaling, cellular activation and tumor proliferation in patients with relapsed and refractory chronic lymphocytic leukemia. Leukemia 2013; 27: 1769.

[24] Sharman J, Hawkins M, Kolibaba K, et al. An open-label phase 2 trial of entospletinib (GS-9973), a selective spleen tyrosine kinase inhibitor, in chronic lymphocytic leukemia. Blood 2015; 125: 2336-2343.

[25] Jeyakumar D and O'Brien S. B cell receptor inhibition as a target for CLL therapy. Best Pract Res Clin Haematol. 2016; 29: 2-14.

[26] Rowley RB, Burkhardt AL, Chao HG, et al. Syk protein-tyrosine kinase is regulated by tyrosine-phosphorylated Ig alpha/Ig beta immunoreceptor tyrosine activation motif binding and autophosphorylation. J Biol Chem. 1995; 270: 11590-11594.

[27] Packard TA, Cambier JC. B lymphocyte antigen receptor signaling: initiation, amplification, and regulation. F1000Prime Rep. 2013; 5 : 40.

[28] Ransom JT, Harris LK, Cambier JC. Anti-Ig induces release of inositol 1,4,5-trisphosphate, which mediates mobilization of intracellular $\mathrm{Ca}^{++}$stores in B lymphocytes. J Immunol. 1986; 137: 708714.

[29] Niiro H, Clark EA. Regulation of B-cell fate by antigen-receptor signals. Nat Rev Immunol. 2002; 2: 945-956.

[30] Seiler T, Dreyling M. Bruton's tyrosine kinase inhibitors in B-cell lymphoma: current experience and future perspectives. Expert Opin Investig Drugs. 2017; 26: 909-915.

[31] Cheng S, Ma J, Guo A, et al. BTK inhibition targets in vivo CLL proliferation through its effects on B-cell receptor signaling activity. Leukemia 2014; 28: 649-657.

[32] Honigberg LA, Smith AM, Sirisawad M, et al. The Bruton tyrosine kinase inhibitor PCI-32765 blocks B-cell activation and is efficacious in models of autoimmune disease and B-cell malignancy. Proc Natl Acad Sci U S A 2010; 107: 13075-13080.

[33] Advani RH, Buggy JJ, Sharman JP, et al. Bruton tyrosine kinase inhibitor ibrutinib (PCI-32765) has significant activity in patients with relapsed/refractory B-cell malignancies. J Clin Oncol. 2013; 31: 88-94.

[34] Herman SE, Gordon AL, Hertlein E, et al. Bruton tyrosine kinase represents a promising therapeutic target for treatment of chronic lymphocytic leukemia and is effectively targeted by PCI-32765. Blood 2011; 117: 6287-6296.

[35] Herman SE, Mustafa RZ, Gyamfi JA, et al. Ibrutinib inhibits BCR and NF-kappaB signaling and reduces tumor proliferation in tissue-resident cells of patients with CLL. Blood 2014; 123: 32863295.

[36] Deeks ED. Ibrutinib: A Review in chronic lymphocytic leukaemia. Drugs 2017; 77: 225-236.

[37] Niemann CU, Herman SE, Maric I, et al. Disruption of in vivo chronic lymphocytic leukemia tumor-microenvironment interactions by ibrutinib-findings from an investigator-initiated Phase II study. Clin Cancer Res. 2016; 22: 1572-1582.

[38] Ponader S, Chen SS, Buggy JJ, et al. The Bruton tyrosine kinase inhibitor PCI-32765 thwarts chronic lymphocytic leukemia cell survival and tissue homing in vitro and in vivo. Blood 2012; 119: 1182-1189.

[39] Dubovsky JA, Beckwith KA, Natarajan G, et al. Ibrutinib is an irreversible molecular inhibitor of ITK driving a Th1-selective pressure in T lymphocytes. Blood 2013; 122: 2539-2549.

[40] Al-Sawaf O, Fischer K, Eichhorst B, et al. Targeted therapy of CLL. Oncol Res Treat. 2016; 39: 768-778.

[41] Gurbity Pálfi T, Fésüs V, Bödör C, et al. State of the art molecular diagnostics and therapy of chronic lymphocytic leukaemia in the era of new targeted therapies. [A krónikus lymphocytás leukaemia korszerű molekuláris diagnosztikája és kezelése az új célzott terápiák korszakában.] Orv Hetil. 2017; 158: 1620-1629. [Hungarian]

[42] Rafei H, Kharfan-Dabaja MA. Treatment of Del17p and/or aberrant TP53 chronic lymphocytic leukemia in the era of novel therapies. Hematol Oncol Stem Cell Ther. 2018; 11: 1-12.

[43] Dicker F, Herholz H, Schnittger S, et al. The detection of TP53 mutations in chronic lymphocytic leukemia independently predicts rapid disease progression and is highly correlated with a complex aberrant karyotype. Leukemia 2009; 23: 117-124.

[44] Zenz T, Eichhorst B, Busch R, et al. TP53 mutation and survival in chronic lymphocytic leukemia. J Clin Oncol. 2010; 28: 4473-4479. 
[45] Stilgenbauer S, Schnaiter A, Paschka P, et al. Gene mutations and treatment outcome in chronic lymphocytic leukemia: results from the CLL8 trial. Blood 2014; 123: 3247-3254.

[46] Fésüs V, Marosvári D, Kajtár B, et al. TP53 mutation analysis in chronic lymphocytic leukaemia. [A TP53-mutáció-analízis jelentősége krónikus lymphocytás leukaemiában.] Orv Hetil. 2017; 158: 220-228.

[47] Malcikova J, Tausch E, Rossi D, et al. ERIC recommendations for TP53 mutation analysis in chronic lymphocytic leukemia-update on methodological approaches and results interpretation. Leukemia 2018; 32: 1070-1080.

[48] Hallek M, Cheson BD, Catovsky D, et al. Guidelines for the diagnosis and treatment of chronic lymphocytic leukemia: a report from the International Workshop on Chronic Lymphocytic Leukemia updating the National Cancer Institute-Working Group 1996 guidelines. Blood 2008; 111: 5446-5456.

[49] Pospisilova S, Gonzalez D, Malcikova J, et al. ERIC recommendations on TP53 mutation analysis in chronic lymphocytic leukemia. Leukemia 2012; 26: 1458-1461.

[50] Malcikova J, Smardova J, Rocnova L, et al. Monoallelic and biallelic inactivation of TP53 gene in chronic lymphocytic leukemia: selection, impact on survival, and response to DNA damage. Blood 2009; 114: 5307-5314.

[51] Zenz T, Habe S, Denzel T, et al. Detailed analysis of p53 pathway defects in fludarabine-refractory chronic lymphocytic leukemia (CLL): dissecting the contribution of 17p deletion, TP53 mutation, p53-p21 dysfunction, and miR34a in a prospective clinical trial. Blood 2009; 114: 2589-2597.

[52] Soumerai JD, Ni A, Xing G, et al. Evaluation of the CLL-IPI in relapsed and refractory chronic lymphocytic leukemia in idelalisib phase-3 trials. Leuk Lymphoma 2018; 8: 1-9.

[53] $\mathrm{Hu} \mathrm{B}$, Patel KP, Chen HC, et al. Routine sequencing in CLL has prognostic implications and provides new insight into pathogenesis and targeted treatments. Br J Haematol. 2019; doi: 10.1111/ bjh. 15877 .

[54] Farooqui MZH, Valdez J, Martyr S, et al. Ibrutinib for previously untreated and relapsed or refractory chronic lymphocytic leukaemia with TP53 aberrations: a phase 2, single-arm trial. Lancet Oncol. 2015; 16: 169-176.

[55] Langerbeins P, Bahlo J, Rhein C, et al. The CLL12 trial protocol: a placebo-controlled double-blind Phase III study of ibrutinib in the treatment of early-stage chronic lymphocytic leukemia patients with risk of early disease progression. Future Oncol. 2015; 11: 1895-1903.

[56] Ahn IE, Farooqui MZH, Tian X, et al. Depth and durability of response to ibrutinib in CLL: 5-year follow-up of a phase 2 study. Blood 2018; 131: 2357-2366.

[57] Byrd JC, Brown JR, O’Brien S, et al. Ibrutinib versus ofatumumab in previously treated chronic lymphoid leukemia. N Engl J Med. 2014; 371: 213-223.

[58] Brown JR, Hillmen P, O’Brien S, et al. Extended follow-up and impact of high-risk prognostic factors from the phase 3 RESONATE study in patients with previously treated CLL/SLL. Leukemia 2017; 32: 83 .

[59] Byrd JC, Hillmen P, O'Brien S, et al. Long-term follow-up of the RESONATE $^{\text {rx }}$ phase 3 trial of ibrutinib versus ofatumumab. Blood 2019; doi: 10.1182/blood-2018-08-870238.

[60] O'Brien S, Jones JA, Coutre SE, et al. Ibrutinib for patients with relapsed or refractory chronic lymphocytic leukaemia with $17 \mathrm{p}$ deletion (RESONATE-17): a phase 2, open-label, multicentre study. Lancet Oncol. 2016; 17: 1409-1418.

[61] Hallek M, Kay NE, Osterborg A, et al. The HELIOS trial protocol: a Phase III study of ibrutinib in combination with bendamustine and rituximab in relapsed/refractory chronic lymphocytic leukemia. Future Oncol. 2015; 11: 51-59.

[62] Chanan-Khan A, Cramer P, Demirkan F, et al. Ibrutinib combined with bendamustine and rituximab compared with placebo, bendamustine, and rituximab for previously treated chronic lymphocyt- ic leukaemia or small lymphocytic lymphoma (HELIOS): a randomised, double-blind, phase 3 study. Lancet Oncol. 2016; 17: 200-211.

[63] Fraser G, Cramer P, Demirkan F, et al. Updated results from the phase 3 HELIOS study of ibrutinib, bendamustine, and rituximab in relapsed chronic lymphocytic leukemia/small lymphocytic lymphoma. Leukemia 2018; doi: 10.1038/s41375-018-0276-9.

[64] Moreno C, Greil R, Demirkan F, et al. Ibrutinib plus obinutuzumab versus chlorambucil plus obinutuzumab in first-line treatment of chronic lymphocytic leukaemia (iLLUMINATE): a multicentre, randomised, open-label, phase 3 trial. Lancet Oncol. 2019; 20: 43-56.

[65] Woyach JA, Ruppert AS, Heerema NA, et al. Ibrutinib regimens versus chemoimmunotherapy in older patients with untreated CLL. N Engl J Med. 2018; 379: 2517-2528.

[66] Shanafelt TD, Wang V, Kay NE, et al. A Randomized Phase III study of ibrutinib (PCI-32765)-based therapy vs. standard fludarabine, cyclophosphamide, and rituximab (FCR) chemoimmunotherapy in untreated younger patients with chronic lymphocytic leukemia (CLL): A Trial of the ECOG-ACRIN Cancer Research Group (E1912). Blood 2018; 132: LBA-4.

[67] Collett L, Howard DR, Munir T, et al. Assessment of ibrutinib plus rituximab in front-line CLL (FLAIR trial): study protocol for a phase III randomised controlled trial. Trials 2017; 18: 387.

[68] Wang ML, Rule S, Martin P, et al. Targeting BTK with ibrutinib in relapsed or refractory mantle-cell lymphoma. N Engl J Med. 2013; 369: 507-516.

[69] Gertz MA. Waldenström macroglobulinemia treatment algorithm 2018. Blood Cancer J. 2018; 8: 40.

[70] Noy A, de Vos S, Thieblemont C, et al. Targeting Bruton tyrosine kinase with ibrutinib in relapsed/refractory marginal zone lymphoma. Blood 2017; 129: 2224-2232.

[71] Byrd JC, Furman RR, Coutre SE, et al. Three-year follow-up of treatment-naïve and previously treated patients with CLL and SLL receiving single-agent ibrutinib. Blood 2015; 125: 2497-2506.

[72] O'Brien S, Furman RR, Coutre S, et al. Single-agent ibrutinib in treatment-naïve and relapsed/refractory chronic lymphocytic leukemia: a 5-year experience. Blood 2018; 131: 1910-1919.

[73] Byrd JC, Furman RR, Coutre S, et al. Up to 7 years of follow-up of single-agent ibrutinib in the Phase $1 \mathrm{~b} / 2$ PCYC-1102 trial of first line and relapsed/refractory patients with chronic lymphocytic leukemia/small lymphocytic lymphoma. In: 60th American Society of Hematology Annual Meeting; December 1-4, 2018; San Diego, CA. Abstract 3133. http://ash.confex.com/ash/2018/webprogram/Paper110847.html.

[74] Woyach JA. How I manage ibrutinib-refractory chronic lymphocytic leukemia. Blood 2017; 129: 1270-1274.

[75] Maddocks KJ, Ruppert AS, Lozanski G, et al. Etiology of ibrutinib therapy discontinuation and outcomes in patients with chronic lymphocytic leukemia. JAMA Oncol. 2015; 1: 80-87.

[76] Jain P, Keating M, Wierda W, et al. Outcomes of patients with chronic lymphocytic leukemia after discontinuing ibrutinib. Blood 2015; 125: 2062-2067.

[77] Lampson BL, Brown JR. Are BTK and PLCG2 mutations necessary and sufficient for ibrutinib resistance in chronic lymphocytic leukemia? Expert Rev Hematol. 2018; 11: 185-194.

[78] Woyach JA, Furman RR, Liu TM, et al. Resistance mechanisms for the Bruton's tyrosine kinase inhibitor ibrutinib. N Engl J Med. 2014; 370: 2286-2294.

[79] Woyach JA, Johnson AJ. Targeted therapies in CLL: mechanisms of resistance and strategies for management. Blood 2015; 126: $471-477$.

[80] Zhou Q, Lee GS, Brady J, et al. A hypermorphic missense mutation in PLCG2, encoding phospholipase $\mathrm{C} \gamma 2$, causes a dominantly inherited autoinflammatory disease with immunodeficiency. Am J Hum Genet. 2012; 91: 713-720.

[81] Walliser C, Hermkes E, Schade A, et al. The phospholipase Cgamma2 mutants R665W and L845F identified in ibrutinib-resistant 
chronic lymphocytic leukemia patients are hypersensitive to the Rho GTPase Rac2 protein. J Biol Chem. 2016; 291: 22136-22148.

[82] Burger JA, Landau DA, Taylor-Weiner A, et al. Clonal evolution in patients with chronic lymphocytic leukaemia developing resistance to BTK inhibition. Nat Commun. 2016; 7: 11589.

[83] Woyach JA, Ruppert AS, Guinn D, et al. BTK(C481S)-mediated resistance to ibrutinib in chronic lymphocytic leukemia. J Clin Oncol. 2017; 35: 1437-1443.

[84] Greaves M, Maley CC. Clonal evolution in cancer. Nature 2012; 481: 306-313.

[85] Ahn IE, Underbayev C, Albitar A, et al. Clonal evolution leading to ibrutinib resistance in chronic lymphocytic leukemia. Blood 2017; 129: 1469-1479.

[86] Komarova NL, Burger JA, Wodarz D. Evolution of ibrutinib resistance in chronic lymphocytic leukemia (CLL). Proc Nat Acad Sci. U S A 2014; 111: 13906-13911.

[87] Albitar A, Ma W, DeDios I, et al. Using high-sensitivity sequencing for the detection of mutations in BTK and PLCgamma2 genes in cellular and cell-free DNA and correlation with progression in patients treated with BTK inhibitors. Oncotarget. 2017; 8: 1793617944.

[88] Condoluci A, Rossi D. Genetic mutations in chronic lymphocytic leukemia: impact on clinical treatment. Expert Rev Hematol. 2019: 1-10.

[89] Reiff SD, Muhowski EM, Guinn D, et al. Non-covalent inhibition of C481S Bruton's tyrosine kinase by GDC-0853: a new treatment strategy for ibrutinib resistant CLL. Blood 2018; 132: 1039-1049.

[90] Reiff SD, Mantel R, Smith LL, et al. The BTK inhibitor ARQ 531 targets ibrutinib-resistant CLL and Richter transformation. Cancer Discov. 2018; 8: 1300-1315.

[91] Johnson AR, Kohli PB, Katewa A, et al. Battling Btk mutants with noncovalent inhibitors that overcome Cys481 and Thr474 mutations. ACS Chemical Biology 2016; 11: 2897-2907.

[92] Bottoni A, Rizzotto L, Lai T-H, et al. Targeting BTK through microRNA in chronic lymphocytic leukemia. Blood 2016; 128: 3101-3112.
[93] Kopp N, Tschuri S, Haebe S, et al. Newer-generation HSP90 inhibitors can overcome ibrutinib resistance and suppress proliferation in human mantle cell lymphoma in vitro and in vivo. Blood 2014; 124: 1686.

[94] Hing ZA, Mantel R, Beckwith KA, et al. Selinexor is effective in acquired resistance to ibrutinib and synergizes with ibrutinib in chronic lymphocytic leukemia. Blood 2015; 125: 3128-3132.

[95] El-Gamal D, Williams K, LaFollette TD, et al. PKC-beta as a therapeutic target in CLL: PKC inhibitor AEB071 demonstrates preclinical activity in CLL. Blood 2014; 124: 1481-1491.

[96] Kuo HP, Crowley R, Xue L, et al. Combination of ibrutinib and BCL-2 or SYK inhibitors in ibrutinib resistant ABC-subtype of diffuse large B-cell lymphoma. Blood 2014; 124: 505.

[97] Zelenetz AD, Barrientos JC, Brown JR, et al. Idelalisib or placebo in combination with bendamustine and rituximab in patients with relapsed or refractory chronic lymphocytic leukaemia: interim results from a phase 3 , randomised, double-blind, placebo-controlled trial. Lancet Oncol. 2017; 18: 297-311.

[98] Lampson BL, Brown JR. PI3Kdelta-selective and PI3Kalpha/ delta-combinatorial inhibitors in clinical development for B-cell non-Hodgkin lymphoma. Expert Opin Investig Drugs 2017; 26: 1267-1279.

[99] Jones JA, Mato AR, Wierda WG, et al. Venetoclax for chronic lymphocytic leukaemia progressing after ibrutinib: an interim analysis of a multicentre, open-label, phase 2 trial. Lancet Oncol. 2018; 19: 65-75.

[100] Hillman P, Rawstron A, Brock K, et al. Ibrutinib plus venetoclax in relapsed/refractory CLL: results of the Bloodwise TAP Clarity Study. Presented at: 2018 ASH Annual Meeting; Dec. 1-4, 2018; San Diego, CA. Abstract 182.

[101] Nitin J, et al. Combined ibrutinib and venetoclax in patients with treatment-naïve high-risk chronic lymphocytic leukemia (CLL). Blood 2018; 132: 696; https://doi.org/10.1182/blood-2018-186.

A cikk a Creative Commons Attribution 4.0 International License (https://creativecommons.org/licenses/by/4.0/) feltételei szerint publikált Open Access közlemény, melynek szellemében a cikk bármilyen médiumban szabadon felhasználható, megosztható és újraközölhető, feltéve, hogy az eredeti szerző és a közlés helye, illetve a CC License linkje és az esetlegesen végrehajtott módosítások feltüntetésre kerülnek. (SID_1) 